\title{
ANTIFUNGAL ACTIVITY OF SYNTHESIZED SUBSTITUTED 1-PHENYL
}

\section{NAPHTHALENE}

\author{
1T. L. Lambat*, ${ }^{2}$ T. B. Deshmukh, ${ }^{3}$ R. P. Mahashabde $\& 4$ S. S. Deo \\ ${ }^{1}$ Department of Chemistry, M. B. Patel College Deori, \\ Dist- Gondia (MS)-441901, India \\ 2,3,4 Department of Chemistry, Institute of Sciences, R.T. Road, \\ Nagpur (MS)-440001, India \\ *Author E-mail: tllambat@gmail.com
}

\begin{abstract}
: -
Laboratory synthesized 1-phenyl naphthoic acid systems (substituted naphthalenes or lignans) were evaluated for their antifungal potential. All the lignan compounds (1a-d) exhibited significant to moderate antifungal activity except the compound (1b) which showed NO toxicity to the fungal species.
\end{abstract}

Substitutions for 1-phenylnaphthoic acid (1):-

\begin{tabular}{|c|c|c|c|c|c|}
\hline Sr. No. & $\mathbf{R}_{1}$ & $\mathbf{R}_{\mathbf{2}}$ & $\mathbf{R}_{\mathbf{3}}$ & $\mathbf{R}_{4}$ & $\mathbf{R}_{5}$ \\
\hline $\mathbf{A}$ & $-\mathrm{H}$ & \multicolumn{2}{|c|}{$-\mathrm{O}-\mathrm{CH}_{2}-\mathrm{O}-$} & $-\mathrm{H}$ & $-\mathrm{H}$ \\
\hline B & $-\mathrm{H}$ & -OMe & -OMe & -OMe & $-\mathrm{H}$ \\
\hline C & $-\mathrm{H}$ & -OMe & $-\mathrm{OMe}$ & $-\mathrm{H}$ & $-\mathrm{H}$ \\
\hline D & $-\mathrm{H}$ & $-\mathrm{OMe}$ & $-\mathrm{OH}$ & $-\mathrm{H}$ & $-\mathrm{H}$ \\
\hline
\end{tabular}<smiles>[R4]c1c([R4])c([R4])c2c(-c3ccccc3)cc(C(=O)O)cc2c1[R4]</smiles>

1-phenylnaphthoic acid (1)

KEYWORDS: - 1 - phenyl naphthoic acids, antifungal potential. 


\section{INTRODUCTION: -}

\section{ANTIMICROBIAL ASSAY: -}

With the indiscriminate use of drugs and antibiotics, microorganisms are attaining resistance to commonly used antibiotics, which leads to downfall of effectiveness of conventional medicines and therefore, search for new antimicrobial agents has become necessary ${ }^{1-3}$. In addition to this problem, antibiotics are sometimes associated with adverse effects on the host including hypersensitivity, immune-suppression and allergic reactions. Such an alarming situation has made its way to the discovery of new effective antimicrobial substances for the treatment of infectious diseases with good therapeutic values. Despite the existence of potent antibiotics and antibacterial agents, resistant or multi-resistant strains are continuously appearing. The substances that can either inhibit the growth of pathogens or kill them and have no or least toxicity to host cells are considered eligible for developing new antimicrobial drugs, may it be a newly synthesized compound or medicinal plant. There is a constant need of new and effective therapeutic agents with no harm to the host ${ }^{4}$. Lignans are known to possess antioxidant and antimicrobial property $^{5}$. So the present work was designed to evaluate the antimicrobial potentials of the lignan compounds namely, 1-phenyl- 6,7methylenedioxy naphthalene-3-carboxylic acid (1a), 1-phenyl-6,7,8trimethoxy naphthalene-3-carboxylic acid (1b), 1-phenyl-6,7 dimethoxy naphthalene-3-carboxylic acid (1c) and 1-phenyl-6-methoxy,7- hydroxylnaphthalene-3-carboxylic acid (1d) that had been synthesized 6 earlier in our laboratory and have shown significant anti-inflammatory activity ${ }^{7}$. 
1-phenylnaphthoic acid (1)

\begin{tabular}{|c|c|c|c|c|c|}
\hline Sr. No. & $\mathbf{R}_{1}$ & $\mathbf{R}_{\mathbf{2}}$ & $\mathbf{R}_{\mathbf{3}}$ & $\mathbf{R}_{4}$ & $\mathbf{R}_{5}$ \\
\hline $\mathbf{a}$ & $-\mathrm{H}$ & \multicolumn{2}{|c|}{$-\mathrm{O}-\mathrm{CH}_{2}-\mathrm{O}-$} & $-\mathrm{H}$ & $-\mathrm{H}$ \\
\hline b & $-\mathrm{H}$ & $-\mathrm{OMe}$ & $-\mathrm{OMe}$ & -OMe & $-\mathrm{H}$ \\
\hline c & $-\mathrm{H}$ & -OMe & $-\mathrm{OMe}$ & $-\mathrm{H}$ & $-\mathrm{H}$ \\
\hline d & $-\mathrm{H}$ & $-\mathrm{OMe}$ & $-\mathrm{OH}$ & $-\mathrm{H}$ & $-\mathrm{H}$ \\
\hline
\end{tabular}

\section{Substitutions for 1-phenylnaphthoic acid (1):-}

\section{MATERIALS AND METHODS: -}

\section{ANTIMICROBIAL ASSAY 8 :-}

Test organism taken for study was Candida albicans.

\section{DETERMINATION OF ZONE OF INHIBITION:-}

Freshly prepared suspensions in sterile water (Optical Density $=0.6$ ) of pure isolated cultures of Candida albicans were mixed with the sterilized Sabouraud dextrose agar maintained at $42.0 \pm 2.0^{\circ} \mathrm{C}$ and poured in petri dish (6 inch) and allowed to solidify. Five wells of $6 \mathrm{~mm}$ diameter were bored in the medium with the help of sterile cork-borer having $6 \mathrm{~mm}$ diameter and were labelled properly and 50, 100, and 200 $\mu \mathrm{g} / \mathrm{ml}$ of the working solution /vehicle and same volume of extraction solvent for control, as well as $25 \mu \mathrm{g} / \mathrm{ml}$ of the standard (Bacitracin) was filled in these wells with the help of micropipette. Similar sets were made for other test compounds. Petri dishes containing Sabouraud dextrose agar for fungal growth were incubated at $24 \pm 2.0{ }^{\circ} \mathrm{C}$ for 5 days. Plates were observed for zone of inhibition.

\section{RESULTS AND DISCUSSION: -}

\section{ANTIMICROBIAL ASSAY: -}

The zone of inhibition was shown by only three lignan compounds (1a, 1c and 1d) against the fungal studied Candida albicans. Bacitracin was taken as standard. From (Table-1) and Graph-1, It can be seen that the compound (1c) showed strong antifungal activity against $C$. albicans than 
(1a) and $1 \mathrm{~d}$ which were equally toxic to $C$. albicans. The increase in concentration of these compounds increased their potency. Compound (1b) didn't show antifungal activity against C. albicans at any concentration. All the values were compared with the standard used.

TABLE-1:- Zone of Inhibition in ( $\mathrm{mm}$ ) against $C$. albicans and the Different Concentration of Substituted 1-phenylnaphthoic acid Used

\begin{tabular}{|c|c|c|c|}
\hline Compounds & $\begin{array}{c}\text { Concentration } \\
(\mu \mathrm{g} / \mathrm{ml})\end{array}$ & Solvent & $\begin{array}{c}\text { C. albicans } \\
\text { Zone of inhibition in } \\
(\mathrm{mm})\end{array}$ \\
\hline $\begin{array}{l}\text { Bacitracin } \\
\text { (Standard) }\end{array}$ & $25 \mu \mathrm{g} / \mathrm{ml}$ & NO Solvent & 16 \\
\hline \multirow[t]{3}{*}{$1 \mathrm{a}$} & $50 \mu \mathrm{g} / \mathrm{ml}$ & \multirow{3}{*}{ Methanol } & 0 \\
\hline & $100 \mu \mathrm{g} / \mathrm{ml}$ & & 0 \\
\hline & $200 \mu \mathrm{g} / \mathrm{ml}$ & & 8 \\
\hline \multirow[t]{3}{*}{$1 \mathrm{~b}$} & $50 \mu \mathrm{g} / \mathrm{ml}$ & \multirow{3}{*}{$\begin{array}{c}\text { Methanol : Water } \\
(1: 1)\end{array}$} & 0 \\
\hline & $100 \mu \mathrm{g} / \mathrm{ml}$ & & 0 \\
\hline & $200 \mu \mathrm{g} / \mathrm{ml}$ & & 0 \\
\hline \multirow[t]{3}{*}{$1 \mathrm{c}$} & $50 \mu \mathrm{g} / \mathrm{ml}$ & \multirow{3}{*}{$\begin{array}{c}\text { Methanol : Water } \\
(1: 1)\end{array}$} & 8 \\
\hline & $100 \mu \mathrm{g} / \mathrm{ml}$ & & 10 \\
\hline & $200 \mu \mathrm{g} / \mathrm{ml}$ & & 10 \\
\hline \multirow[t]{3}{*}{$1 d$} & $50 \mu \mathrm{g} / \mathrm{ml}$ & \multirow{3}{*}{ Methanol } & 8 \\
\hline & $100 \mu \mathrm{g} / \mathrm{ml}$ & & 8 \\
\hline & $200 \mu \mathrm{g} / \mathrm{ml}$ & & 8 \\
\hline
\end{tabular}

\section{Graph -1:-}

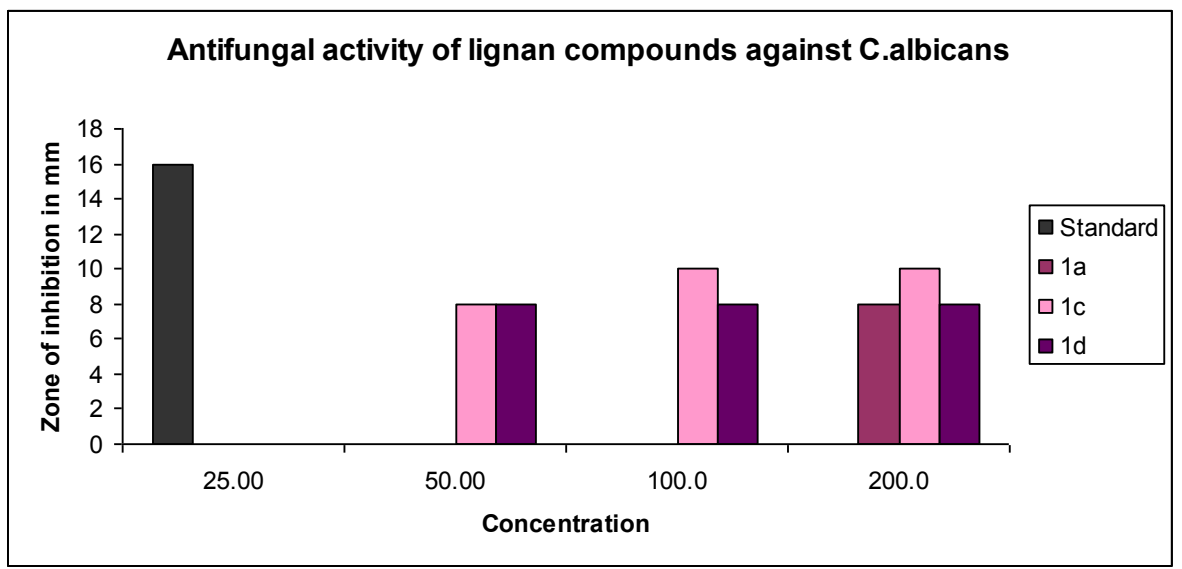




\section{CONCLUSION: -}

All the phenyl naphthoic acids have shown considerable toxicity to the fungal species tested. Unexpectedly the compound (1b) tested showed NO toxicity to the fungal species. The compound (1c) was found to be the most active antifungal agent.

\section{ACKNOWLEDGMENTS:-}

The authors express their sincere thanks to Dr. M. T. Bharambe, Director Govt. Institute of Science, Nagpur, for providing the necessary research facilities and authorities of SKB College of Pharmacy, Kamptee for biological assay.

\section{REFERENCES: -}

Service R F, (1995). Science, 270, 724-727.

Agrawal P, Rai V, and Singh R B, (1996). Int. J. of Clin. Pharm. and Therap., 34, 406-409.

Venugopal A, and Dasani S, Rai , (2009). Elec. J. of Biol., 5(2), 40-44

Ahmad I, and Beg A Z, (2001). J. of Ethnoph., 74, 113-123 Chun H, Kitts D D, (2007)

Deo S S, Inam F , Mahashabde R P, and Jadhav A N, (2010) Asian Journal of Chemistry, 22(5) , $3362-3368$

Deo S S, Inam F , Mahashabde R P, and Jadhav A N, (2010) Asian Journal of Chemistry, 22(9) , 7423-7425

Joshi B, Lekhak S, and Sharma A, (2009) Kathmandu University Journal Of Science, Engineering And Technology., 5(1), 143- 150 